\title{
ARTICLES
}

CENTRAL EUROPEAN REVIEW OF ECONOMICS \& FINANCE

vol. 33, No. 2(2021), pp. 5-22

DOI https://doi.org/10.24136/ceref.2021.004

Anna Mężyk ${ }^{1}$

\section{EU RAIL PASSENGER TRANSPORT - AN IMPORTANT DETERMINANT OF SUSTAINABLE DEVELOPMENT}

\begin{abstract}
The 2030 Agenda for Sustainable Development has become the global blueprint for sustainable development. Sustainable development is supposed to change functioning of societies and economies in order to minimize negative ecological effects, at the same time providing for the needs of present and future generations. Due to its functions, transport is indispensable for meeting these needs, but it also generates demand for energy resources and has a negative impact on the environment. Appropriate shaping of transport systems is, therefore, an important element of the transformation of economies towards sustainable development and thus a key task for government policy.

Rail is among the most energy efficient modes of transport for freight and passengers. The aim of this article is to assess the development of rail passenger transport in European Union countries on the basis of statistical data in the context of the need to transform mobility systems in accordance with the principles of sustainable development. The analysis of the data shows that the development of rail transport is low compared to road and air transport, which raises questions about the reasons for this fact and the further measures needed.
\end{abstract}

\footnotetext{
${ }^{1}$ Dr hab. inż., prof. UTH, Kazimierz Pulaski University of Technology and Humanities in Radom, Faculty of Economics and Finances
} 
Key words: sustainable development goals, transport policy, rail passenger services, high speed rail, service usability

JEL classification: L380 - Public Policy; L920 - Railroads and Other Surface Transportation

Paper type: Theoretical research article

\section{INTRODUCTION}

The 6th report of the UN's Intergovernmental Panel on Climate Change (IPCC), published in August 2021, leaves no doubt - civilization is in a situation of urgent need to combat climate change through rapid and deep cuts in greenhouse gas emissions causing global warming. This requires radical changes in the principles of functioning of economies and societies. The new rules that should be applied are familiar to societies. The first warnings against over-exploitation of resources and pollution of the Earth appeared already in the 1970s in the Club of Rome report "Limits to Growth". Subsequent initiatives and work undertaken by UN commissions and teams led to the formulation of concepts and principles of sustainable development, and guidelines for its implementation.

In 1983, the United Nations General Assembly established the World Commission on Environment and Development (WCED). The Commission was tasked with developing long-term environmental strategies to achieve sustainable development by the year 2000 and beyond. It was also tasked with making recommendations for improving international cooperation on environmental protection, taking into account the different phases of economic and social development. The Commission's report "Our Common Future", published in 1987 and known as the Brundtland Report, is considered a major contribution to the global model of sustainable development. This report included the postulate of sustainable development, which is about meeting the needs of the present generation without compromising the ability of future generations to meet their own needs. (UN, 1987, p.54)

Another important contribution to the sustainable development process at the global level was the United Nations Conference on Environment and Development (UNCED) in Rio de Janeiro in June 1992. At the Rio Conference, 178 participating countries committed themselves to the guiding principle of global sustainable development. During the conference, states were able to agree on common solutions, which, among other things, constituted agreements for future environmental and development cooperation. Already in these first documents the important role of transport and the consequences of its development for the environment were pointed out. The EU adopted a strategy for sustainable development in 2001. 
Sustainable development has officially become one of the long-term objectives of the European Union in accordance with Article 3(3) of the Treaty on European Union. (EU, 2012, p.17)

The 2030 Agenda for Sustainable Development, adopted in 2015 by 193 countries of the United Nations and comprising 17 Sustainable Development Goals (SDGs), has become the global blueprint for sustainable development. Sustainable development - is a development path that takes into account the current needs of all people without compromising future generations and their needs, based on three pillars: economic, environmental and social. An efficient transport system is one of the basic sectors of the wellfunctioning economy and an important component of life quality. Economic development entails an increase in transportation needs in the transport of goods and people, putting new requirements for ensuring the smooth flow of goods and mobility of people. At the same time, transport has a negative impact on the environment, contributing to climate change and global warming. These include greenhouse gas emissions, air, noise and water pollution, but also accidents, road crashes and congestion. Halting these changes has become a challenge for the present generation.

In the European Union, transport currently accounts for around a quarter of total greenhouse gas emissions (EC, 2018, p.7). Assuming a moderate economic growth over the long term, it is predicted that between 2010 and 2050 there will be an increase in demand for passenger transport of approximately $42 \%$ and for freight of $60 \%$ between 2010 and 2050 (EC, 2017, p.22). Reconciling the need for economic development and halting environmental degradation requires a shift in the EU transport system towards an environmentally friendly system. Rail transport, which has much lower external costs than road or air transport and a large and, in addition, underutilized transport potential, can play an important role in such a system. Rail is among the most energy efficient modes of transport for freight and passengers - while the rail sector carries $8 \%$ of the world's passengers and $7 \%$ of global freight transport, it represents only $2 \%$ of total transport energy demand. (IEA,2019, p.25). Underlining the importance of this form of transport for future sustainable development, the European Commission has declared 2021 to be the European Year of Rail. 


\section{A VISION FOR RAILWAYS IN THE EUROPEAN TRANSPORT POLICY PROGRAMS}

A consistent policy to strengthen rail transport has been one of the priorities of European transport policy since the early 1990s. In the initial period, rail policy focused on three areas which created the conditions for the efficient and effective functioning of railway undertakings. They were:

- creation of a common railway market (through deregulation and liberalization),

- restructuring and revision of the functioning of state-owned railways,

- modernization of the railway infrastructure.

The measures taken led to the elimination of barriers to rail transport between EU Member States, to clear development of the supply side of the railway market and the emergence of new, also private carriers. These changes were accompanied by investments in railway infrastructure, also funded by large amounts of EU funds. These achievements are indisputable progress in the modernization of institutional structures and turn close this branch of the transport requirements of modern economies. However, in relation to the volume of freight, rail policy effects are rather moderate, although varied in different EU countries.

Key actions identified in the White Paper of 2011 have to bring structural changes to the railway sector and to increase rail network bandwidth. (EC, 2011, p.9-10) In particular, these are the following:

- tripling the length of the existing high-speed rail network by 2030,

- maintaining a dense conventional rail network in all Member States of the European Union,

- increasing the capacity and improving the quality of railway network,

- integrating railways into the multimodal urban travel and transport network by better integrating all forms of public transport, including the transformation of transport points (airports, stations, stations, ports) into multimodal connection platforms,

- development of multimodal internet information, electronic reservation and payment systems.

The 2011 White Paper program also sets specific transport objectives for rail transport, including the takeover by rail of the majority of passenger traffic over medium distances by 2050. An important action in relation to passenger transport is the integration of railways in public transport systems. This is not a new direction. The developed concept of integrating all forms of passenger transport in all possible areas was already presented by the European Commission in 1995 in the Green Paper on a Citizens' Network (EC, 1995). In order to support these measures, the introduction 
of extended and more precise ex-ante evaluation criteria for projects was announced, which will guarantee selection for implementation only of projects bringing real economic and social benefits. This may mean opportunities for less capital-intensive projects, but yielding desirable effects, such as the integration of conventional rail into other public transport systems or behavioral changes, to stimulate demand for public transport. Increasing the share of rail in meeting the transport needs of the economy and society is one of the permanent priorities of the European Union's transport policy since the 1990s. However, the transport sector's greenhouse gas emissions have increased over time and now account for up to a quarter of total EU emissions (EU, 2019, p.1).

The EU's current transport program, the 2020 Strategy for Sustainable and Smart Mobility, continues to prioritize supporting cohesion, reducing regional disparities and improving connectivity and access to the internal market for all regions. The vision for future transport is "Greening mobility", which must be the new license for the transport sector to grow (EU, 2020, p.2). Mobility in Europe should be based on an efficient and interconnected multimodal transport system, for both passengers and freight, enhanced by an affordable high-speed rail network. Rail is one of the most sustainable, innovative and safest transport modes. To experience this, 2021 has been declared the European Year of Rail.

The time has passed. As stated in point 9 of the transport vision presented in the document, Europe needs to change the existing paradigm of incremental change and undertake a fundamental transformation. In order to realize the vision, the strategy identifies 10 flagship initiatives and an action plan for the work in the coming years. As for the railways it is assumed that high-speed rail traffic will double by 2030 and triple by 2050 and by 2050 rail freight traffic will double. (EC, 2020, p.3) To transform the transport sector into a truly multimodal system of sustainable intelligent mobility services, Europe needs to build a high-quality transport network with high-speed rail services for short distances and green aviation services to increase the number of connections on longer routes. (EC, 2020, p.9) 


\section{PASSENGER TRANSPORT ON HIGH-SPEED RAILWAY LINES}

In the overall volume of rail passenger transport, several segments are distinguished according to the needs served, coverage and technical solutions: urban and agglomeration transport, regional transport and interregional transport. In the inter-regional transport segment carriage is further provided on the conventional, upgraded lines allowing traffic at speeds on the main segments equal to or greater than $200 \mathrm{~km} / \mathrm{h}$ and on lines newly built for this purpose with speeds exceeding $250 \mathrm{~km} / \mathrm{h}$ (HSR - high speed rail). The high-speed railway network is designed mainly to serve traffic between large urban agglomerations, usually connecting the capital of the country with the largest cities of social and economic importance. The first such lines in the EU were built in 1985 in France and Italy. By the year 2000, the construction of HSR lines in Germany, Spain and Belgium had been commenced. In 2000, the total length of high speed railway lines was $3014 \mathrm{~km}$. The first decade of the 21st century saw a dynamic acceleration in the construction of new lines and the consequent doubling of their length. In 2010, high speed railway lines have been constructed on the territory of the 7 EU Member States (including Great Britain), and at the end of year had a total length of $8268 \mathrm{~km}$.

The dedicated HSR lines in operation are located in seven EU Member States, with the largest length in Spain (3 $015 \mathrm{~km})$ and France $(2735 \mathrm{~km})$. Relatively long, about one thousand kilometres are also the dedicated HSR networks in Germany $(1223 \mathrm{~km})$ and in Italy $(896 \mathrm{~km})$. The shortest dedicated HSR networks, less than $100 \mathrm{~km}$ in operation are in Denmark $(56 \mathrm{~km})$ and in Netherlands $(90 \mathrm{~km})$. The HSR network in Belgium has the length of $209 \mathrm{~km}$.

In Poland is since 2015 only one line in operation, after modernisation suitable to higher speeds. The length of it is $224 \mathrm{~km}$ and no new lines have been adapted to high speed since than. The length of HSR lines in operation and under construction in the EU is presented in Table 1. 
Table 1. The length of high speed railway lines in the EU

\begin{tabular}{|c|c|c|c|c|c|c|c|}
\hline \multicolumn{8}{|c|}{ High-speed railway lines [km] } \\
\hline & 1990 & 2000 & 2010 & 2015 & 2020 & $\begin{array}{c}\text { Under } \\
\text { construction }\end{array}$ & $\begin{array}{c}\text { Start } \\
\text { of operation }\end{array}$ \\
\hline & \multicolumn{5}{|c|}{ Lines in use $[\mathrm{km}]$} & {$[\mathrm{km}]$} & \\
\hline UE & 1025 & 3014 & 8268 & 10037 & 11526 & 2104 & \\
\hline ES & - & 471 & 2102 & 3002 & 3487 & 1135 & $2021-2028$ \\
\hline FR & 717 & 1290 & 1912 & 2058 & 2734 & - & - \\
\hline $\mathrm{DE}$ & 90 & 576 & 1178 & 1381 & 1571 & 147 & $2022-2025$ \\
\hline $\mathrm{FI}$ & - & 156 & 1120 & 1120 & 1120 & - & \\
\hline IT & 194 & 238 & 856 & 856 & 921 & 327 & 2022 \\
\hline SE & - & 187 & 680 & 860 & 860 & 214 & $2024-2035$ \\
\hline AT & 24 & 24 & 121 & 237 & 254 & 281 & $2022-2027$ \\
\hline $\mathrm{PL}$ & - & - & - & 224 & 224 & - & - \\
\hline $\mathrm{BE}$ & - & 72 & 209 & 209 & 209 & - & - \\
\hline $\mathrm{NL}$ & - & - & 90 & 90 & 90 & - & - \\
\hline DK & - & - & - & - & 56 & - & - \\
\hline UK & - & - & 113 & 113 & 113 & & \\
\hline
\end{tabular}

Source (EU Transport in Figures, 2021, 81 )

The data in the table indicate that HSR lines are operated mainly in the countries of the "old" EU, while in the countries that acceded to the Community in 2004 and later is only one such line (in Poland). In relation to the entire rail network, these lines represent less than $6 \%$ of the total railway lines length (11526 km among $200161 \mathrm{~km}$ ). In the near future the situation will not fundamentally change, since the construction of new high-speed lines in the greatest extent is conducted only in Spain and to a lesser extent in other countries, continuing the expansion of existing networks. New, longer lines are being built only in Austria and Sweden. The country with the longest HSR network in operation - Spain - is at the same time building the longest network of new lines. This clearly demonstrates the usefulness and popularity of this form of transport and the benefits it brings. After completion of construction in 2029, the length of the HSR network in the EU will be $13630 \mathrm{~km}$.

Only two types of data on rail passenger transport are available in the statistics collected by Eurostat: high-speed and total. High-speed services include services performed by high-speed rolling stock, e.g. tilting trains, travelling at speeds of $200 \mathrm{~km} / \mathrm{h}$, not necessarily on infrastructure built for high speeds. Subject to this disclaimer, high speed transport is carried out in $12 \mathrm{EU}$ countries, in addition to those mentioned above also in the Czech Republic, Portugal and Slovenia. Data on the development of passenger rail services, including high-speed rail services, are shown in the table 2 and figure 1. 


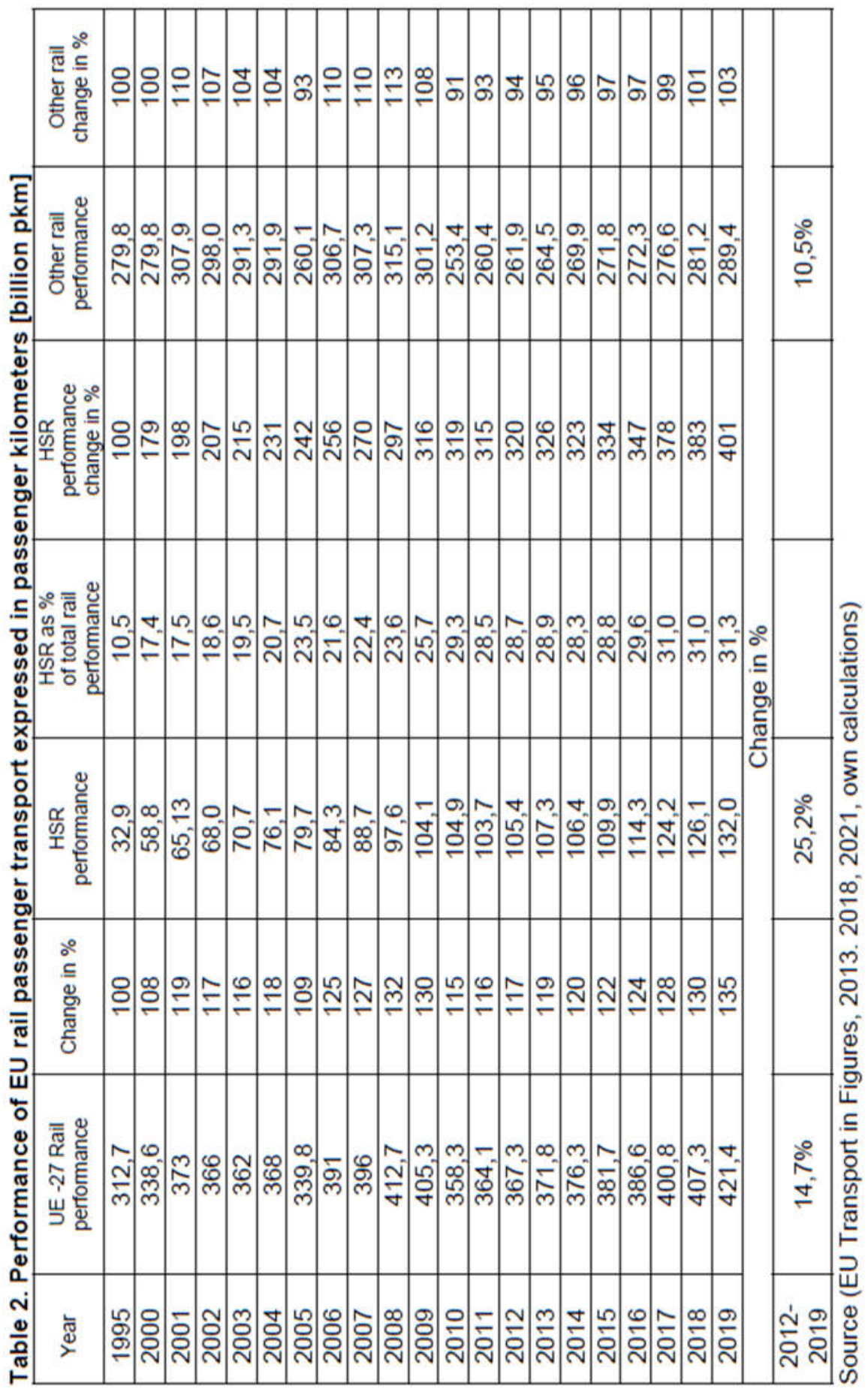


The HSR transport segment is growing steadily. Passenger transport by high-speed rail has quadrupled since 1995 and increased by over $25 \%$ since $2012^{2}$. This is disproportionate to the increase in the length of the HSR network. The length of new HSR lines increased from $6825 \mathrm{~km}$ to 11526 during this period, which means an increase of nearly $69 \%$ (Engelhardt J., 2019, 3). However, the share of HSR passenger transport in the total rail passenger market has not increased significantly. In 2012, the HSR transport segment (incl. tilting trains able to run $200 \mathrm{~km} / \mathrm{h}$ ) accounted for $28.7 \%$ of the total rail passenger transport in the EU and in 2019 it was only 2.6 percentage points more, giving $31.3 \%$ (in billion pkm).

Conventional rail passenger transport volume increased during this period by only $10 \%$, what together with the HSR resulted in an increase of total rail passenger services volume accounting to $14.7 \%$.

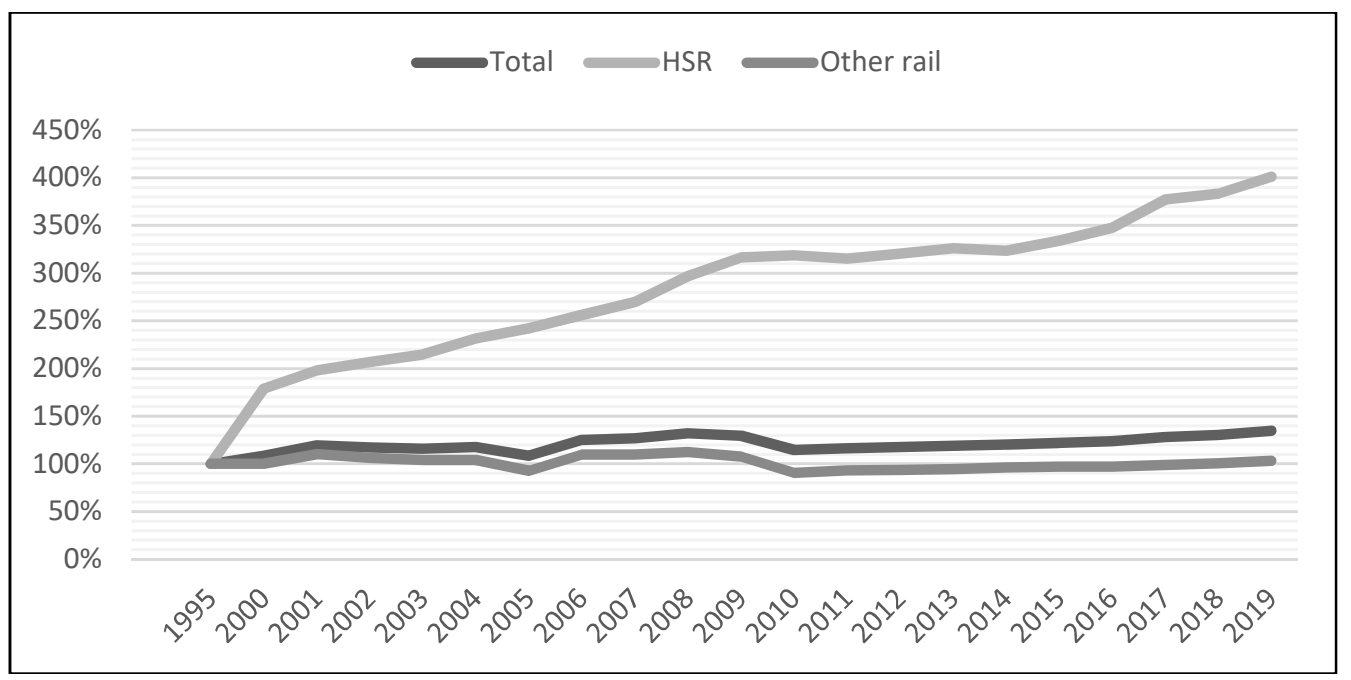

Fig. 1 EU Rail passenger service performance

Source: own elaboration, based on: EU Transport in Figures, 2013, 2018, 2021

${ }^{2} 2008$-2011 were a time of global economic crisis, which affected the operation of rail transport. 
In Poland in 2004 rail passenger transport amounted to 28,2 billion pkm and declined until 2015, when its value was 17.4 billion paskm. Since that year there has been a significant increase of $27 \%$ to 22.1 billion pkm. However, this is still much below the value in 2004 (EU, 2021, p. 53-54).

The largest volume of HSR transport is carried out in France. The HSR performance in this country in 2019 amounted to 59,95 billion pkm, which constituted over $58 \%$ of the total rail performance in France and $45 \%$ of the high speed rail transport in the all EU countries. Apart from France, the leaders of high speed rail transport in the EU include Spain, Germany, Italy and Sweden. In total, high-speed rail transport in these five countries accounts for $92 \%$ of all HSR transport in the EU, equivalent to 132 billion pkm (EU,2021,p.54). The data in Table 3 show the development of the rail passenger transport in both main types of rail passenger services in the leading HSR- countries. 


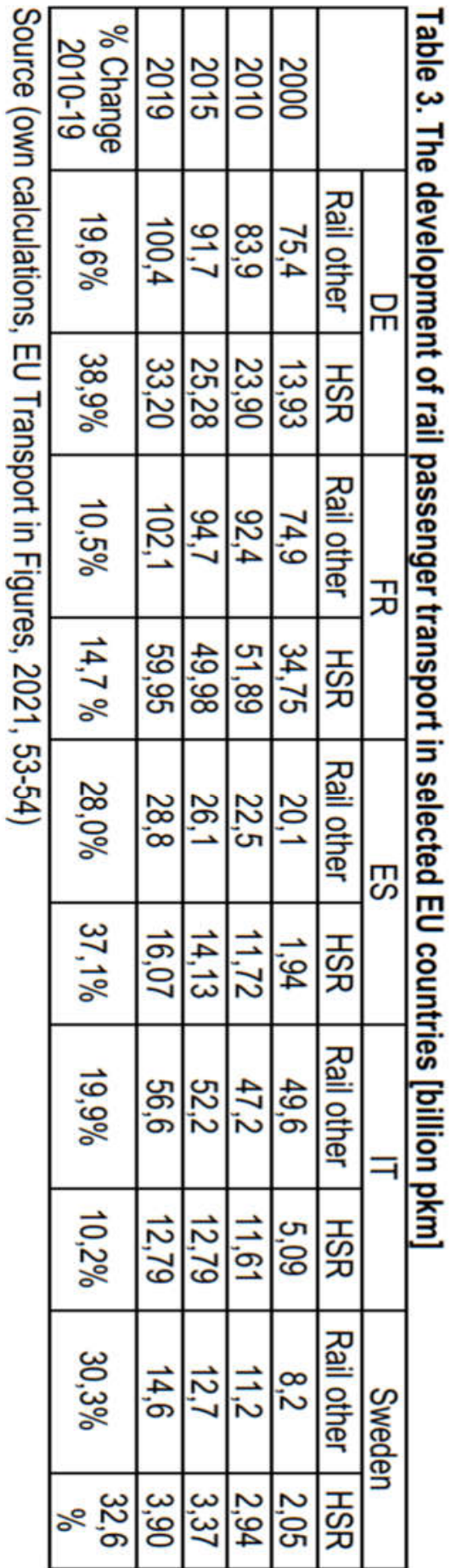


With an HSR network twice as long as Germany's, Spain carried only 16.07 billion pkm in 2019, half of the Germany's volume. This is clearly related to the population and population density, which is 231 inhabitants per square kilometer in Germany and only 80 in Spain (European mainland). An important issue is also the connection of high-speed railway lines with the local transport system of the region through which they run. Consequently, the question arises about the economic efficiency of the HSR network and the conditions that justify its construction and spending public money.

In Poland performance of HSR transport is counted since 2005, when the volume of this mode of rail amounted to 0.47 billion pkm. In 2019, the passenger volume on this only HSR line was already $1.68 \mathrm{pkm}$, four times bigger, representing $7.6 \%$ of total passenger rail services.

The market success of high speed rail is undoubtedly connected with a huge quality leap in the railway offer, primarily with a significant reduction in travel time within the range of average distances of $300-500$ $\mathrm{km}$. The first European high-speed line, the LGV Paris-Sud-Est, linking France's two largest conurbations, Paris and Lyon, has made it possible to cut journey times between them from 4 to 2 hours (Masel A., 2006, 35). High-speed rail travel has become an attractive alternative to air transport, so a significant part of HSR passengers are customers taken over from air transport. Conventional railways are also important, complementing the network of high-speed lines and creating an integrated mobility network, which is what the EU is aiming for. The superior quality of transport services provided on HSR lines is reflected in significantly higher dynamics of development of this segment, as shown in the table 3 (except Italy).

\section{MODAL SPLIT OF PASSENGER TRANSPORT IN THE EU}

Railways operate in $27 \mathrm{EU}$ countries, except Cyprus and Malta. Between 2010 and 2019, there has been an increase in the transport volume and in the share of rail services in the passenger transport market, both in the high-speed and conventional rail segments. The systematic development of agglomeration and metropolitan railway systems is a factor stimulating an increase in the volume of traffic on conventional rail. Serving metropolitan cities and agglomerations is that area of transport, where the railway finds the most effective conditions for functioning, resulting from the mass nature of transport needs. This in turn translates into a good quality offer and its popularity. The data in Table 4 illustrate changes of modal split of the passenger transport in the EU (without Great Britain). 
Table 4. Passenger transport in the EU [billion pkm]

\begin{tabular}{|c|c|c|c|c|}
\hline EU & 2000 & 2010 & 2019 & $\begin{array}{c}2010- \\
2019\end{array}$ \\
\hline Passenger transport total & 5001 & 5411 & 6038 & $7,1 \%$ \\
\hline Railways total & 338,6 & 358,3 & 421,4 & $17,6 \%$ \\
\hline EU HSR & 58,8 & 104,7 & 132,01 & $25,9 \%$ \\
\hline Railways share [\%] & 6,8 & 6,6 & 7,0 & \\
\hline HSR share in passenger tr. total & 1,2 & 1,9 & 2,1 & \\
\hline [\%] & 496,5 & 482,2 & 486,7 & $0,9 \%$ \\
\hline Bus \& coaches & 9,9 & 8,9 & 8,1 & \\
\hline Bus \& coaches share [\%] & 3660,4 & 3975,9 & 4325,0 & $4,4 \%$ \\
\hline Passenger cars & 73,2 & 72,7 & 71,6 & \\
\hline Passenger cars share [\%] & 313,3 & 377,9 & 582,9 & $33,3 \%$ \\
\hline Air & 6,3 & 7,0 & 9,7 & \\
\hline Air share [\%] & & &
\end{tabular}

Source (EU Transport in Figures, 2021, 53 - 80)

Individual motorization, despite a slight decline since 2000, accounts for the largest share of passenger transport $(71,6 \%)$, due to its flexibility and importance in serving the so-called "last mile" and door-to-door connections. This situation is therefore unlikely to change much in the coming years.

The second largest share of passenger transport in the EU is held by air transport, at 9,7\%. This mode of transport had also the highest growth rate over the whole period considered (except for the initial period of development of the HSR). Consequently, the share of air transport in passenger transport in the EU is higher than the share of passenger rail transport.

The increase in transport performance on HSR lines was at nearly $25,9 \%$ compared to $17,6 \%$ on conventional railways. As a result the share of rail services in the total passenger transport market slightly increased from 6.6 to $7,0 \%$ (Table 4). The most likely cause for these changes may be an increase in demand in the segment of agglomeration rail transport related to dynamic suburbanization processes. In the conditions of growing road traffic and congestion, agglomeration railways are an attractive alternative to daily commuting. In conclusion, both segments of the rail passenger market included in the statistics show positive development dynamics in recent years. Rail passenger transport has shown a higher growth rate than total passenger transport in the EU, which is an expected effect in the light of transport policy and sustainable development. 
Short travel times, achieved through high speeds, are undoubtedly a great advantage of the HSR railways, which speaks in favour of their development. This will depend however on the availability of sufficient funds. As the ECA points out, high-speed rail infrastructure is expensive, the lines audited costed, on average, 25 million euros per kilometre. The level of cost reasonableness is low (ECA, 2018, p.58). Most of the construction and maintenance costs of rail infrastructure are covered by the Member States. As the European Commission points out, investment expenditures on the development of transport infrastructure amounting to $2.7 \%$ of GDP in 2016 were the lowest in 20 years [EC, Trends, 23].

This fact has also a negative impact on the maintenance of the existing, conventional railway network. As data show, the conventional rail network in the EU is shrinking. Since 2010, the length of the rail network has decreased in seventeen EU countries and only in ten countries has increased. The data in Table 5 illustrate the changes in the length of the rail network in selected EU countries.

Table 5. Rail lines in use in selected EU countries

\begin{tabular}{|c|c|c|c|c|}
\hline & \multicolumn{2}{|c|}{ Lines in use $[\mathrm{km}]$} & \multicolumn{2}{c|}{$\%$ Change } \\
\hline & 2010 & 2019 & Decrease & Increase \\
\hline UE-27 & 203847 & 200161 & $-1,8$ & \\
\hline BE & 3582 & 3602 & & 0,6 \\
\hline DK & 2606 & 2646 & & 1,5 \\
\hline DE & 37679 & 39379 & & 10,7 \\
\hline EE & 919 & 1033 & & 12,4 \\
\hline ES & 15837 & 15718 & $-0,7$ & \\
\hline FR & 30335 & 27483 & $-6,5$ & \\
\hline IT & 17022 & 16779 & $-1,4$ & \\
\hline NL & 3013 & 3055 & & 1,4 \\
\hline AT & 5039 & 4968 & $-1,4$ & \\
\hline PL & 19702 & 18538 & $-5,9$ & \\
\hline LV & 1897 & 1860 & $-1,9$ & \\
\hline HU & 7893 & 7588 & $-3,8$ & \\
\hline RO & 10777 & 10759 & $-1,6$ & \\
\hline FI & 5919 & 5923 & - & - \\
\hline SE & 11160 & 10899 & $-2,3$ & \\
\hline
\end{tabular}

Source (EU Transport in Figures, 2021, p.80, own calculation) 
The largest decrease in the length of the rail network occurred in France and Poland, while the highest increase of $1700 \mathrm{~km}$ occurred in Germany, where the rail network is still the longest in the EU. There is also a noticeable decrease in the length of lines in operation in the Central and Eastern European countries that joined the EU in 2004.

\section{CONDITIONS FOR DEVELOPMENT OF EU RAIL PASSENGER TRANSPORT}

Increasing the use of rail transport to meet the transport needs of the economy and society is one of the most important issues in European transport policy. Despite detailed legal regulations and significant financial support, both from EU funds (TEN-T network) and national funds, the actions undertaken have brought moderate results in terms of increasing the volume of rail transport, which is confirmed by the analysis presented in the previous part of this article. Measures supporting the functioning of rail transport must be continued, but enriched with market-effective and economically efficient actions.

The overriding, current objective of the European transport policy is to link the national transport systems into one common Community transport system. This system should be able to satisfy increasing transport needs while consuming fewer energy resources and having less negative effects on the environment $(E C, 2011,3)$. But, as stated in the special report of ECA, there is no real high-speed European rail network - only a patchwork of national high-speed lines. Work on cross-border sections of HSR is not being finalized in a coordinated manner. The Court's assessment of the maximum "speed yield" clearly shows also, that HSR services are not always needed - in most cases, lines are only achieving an average speed of around $45 \%$ of design speed. this means low added value for EU co-financing of high-speed rail infrastructure investments in the Member States (ECA, 2018, 64, 65).

An indispensable condition for the effectiveness of the railway are investments allowing for an increase in capacity and modernization of the railway network. The EU transport policy documents emphasize the need to spend money only on projects with real added value for the EU. As it results from the earlier analysis of statistical data, the most dynamically developing segment of rail passenger transport in the EU is transport on HSR lines. Previous undertakings in this area, implemented in France, Germany or Spain, have been a great market and financial success. However, it would be simplistic to conclude that any project in this area will bring similar economic benefits. The key issue for the success of the new HSR lines, and also for the realization of the White Paper's objective, i.e. for railways to take over the handling of a larger 
proportion of passengers than before, is to generate sufficiently high demand for rail transport so that both the new and old lines are used. Running a profitable operation on the HSR line, due to the high costs of access to the infrastructure, requires a very high number of passengers, in the order of 9 million per year or at least six million passengers in the year of commissioning (ECA, 2018, p.43)

Analyzing the economic effects of selected, similar infrastructural investments in transport, T. Leunig noted that the greatest benefits from the construction of a new connection occur when the connection makes it possible to reach new markets, gives wider possibilities of choice or opens new spaces, necessary for the development of economic activity (Leunig T., 2011). Building a connection as such does not necessarily mean obtaining economic benefits that exceed the outlay. The benefits will be greater the greater the difference between the existing and the new link. Hence the conclusion that the decisive factor for society is the broadly understood increase in the usefulness of the new connection in relation to the existing one, taking into account the costs of the service, and not only the absolute reduction in travel time. This may provide opportunities for projects which are less capital intensive but which have the required effect, such as the aforementioned integration of conventional rail with other high speed rail systems or projects aimed at behavioral changes enabling a stimulation of demand for public transport. (EC, 2011, p.10).

The increase in utility of a new connection can be estimated by examining the willingness to pay of potential passengers for the new service. The volume of this new demand should be large enough to ensure the viability of the whole system. It should be noted that an increase in transport on HSR lines may be accompanied by a decrease in transport on conventional rail lines and a decrease in the number of airline customers, which means economic losses for the carriers operating them.

\section{CONCLUSIONS}

Despite political and financial support, the development of rail passenger transport in the European Union is showing a weak dynamism. All segments of rail passenger transport require substantial public support and funds for investments. High-speed rail requires investment in new lines and rolling stock, regional and agglomeration railways need support for an attractive, regular and relatively low-cost offer, and low-burden lines generate a deficit. This situation puts public budgets in a difficult position. As a result, rail transport growth is observed mainly in countries with a high level of economic development, which are able to devote significant funds to the development of HSR system and to subsidize other segments of rail transport. 
The ever decreasing availability of public funds to finance transport projects requires a careful analysis of possible solutions which would achieve the same goals. The objective set out in the White Paper 2011 - to increase the share of rail in passenger transport - involves considerable expenditure, whether on building new high-speed rail lines or on significantly improving the usefulness of conventional rail services in an integrated transport system (EC, 2011,10).

In order to strengthen the role of the railway it is crucial to generate a high demand for its services. It is important that both - high-speed and conventional lines - are sufficiently exploited. Poor use of certain lines will lead to difficulties in maintaining and upgrading the whole network. It will therefore be difficult to maintain the current density of the conventional lines network, contrary to the vision of rail transport adopted in the European policy agenda and necessary, if the European transport system is to become environmentally friendly. There are opportunities to attract passengers by increasing the utility of rail service, defined by three factors: speed, reliability and cost. Speed should be considered in terms of the entire door-to-door journey time and not only as the speed of travel.

The aim of actions taken should be increasing the speed and comfort of travel, e.g. through access to dynamic information, better connected trains, improved transfer between sections of the journey, combining the rail offer with other mobility models, such as On-Demand-Transport, car and bike-sharing, ride-hailing. These are measures aimed at integrating railways with other public transport systems, which is in line with the strategy for sustainable and intelligent mobility proposals. High-speed railway lines, like motorways, should not constitute a 'tunnel', i.e. an autonomous transit corridor, which only crosses a region and does not generate any economic stimulus in the surrounding area.

A modern, integrated transport system, well serving societal and economic needs, is not only an objective of EU transport policy, but should also be the subject of a broader discussion among practitioners and customers. Linking new rail lines to existing passenger transport systems, accessibility and ease of its use is a key to exploiting the full potential of the railways and provide an economic justification for incurring the high costs of its construction. In order to make rational decisions on how to achieve this objective, it is necessary to include in the analysis a wide range of economic, social and environmental impacts and costs of the project, as well as to conduct in-depth studies on the development of demand in the macro-economical conditions of a given country. 


\section{REFERENCES}

1. Engelhardt J., 2019, The perspectives of development of high-speed rail network in the European Union till the year 2050, Przegląd Komunikacyjny, nr 7.

2. European Commission, EC, 1995. CITIZEN' S NETWORK - Fulfilling the potential of public passenger transport in Europe. Green Paper, COM(1995)601, Brussels.

3. European Commission, EC, 2011. Roadmap to a Single European Transport Area - Towards a competitive and resource efficient transport system. White Paper COM(2011) 144 final, Brussels.

4. European Commission, EC, 2017. Europe on the Move. An agenda for a socially fair transition towards clean, competitive and connected mobility for all. Communication from the Commission, COM(2017) 283 final, Brussels.

5. European Commission, EC, 2018. A Clean Planet for All. A European strategic long-term vision for a prosperous, modern, competitive and climate neutral economy. Communication from the Commission, COM(2018)773 final. Brussels.

6. European Commission, EC, 2019. Transport in the European Union. Current Trends and Issues. Brussels.

7. European Commission, EC, 2020. Sustainable and Smart Mobility Strategy - putting European transport on track for the future, COM (2020) 789 final, Brussels.

8. European Commission, EC, 2021. EU Transport in Figures. Statistical Pocketbook 2021. Brussels.

9. European Court of Auditors, ECA, 2018, A European high-speed rail network: not a reality but an ineffective patchwork. Special report, nr 19

10. European Union, EU (official Journal), 2012. Consolidated Version of the Treaty on European Union, Brussels.

11. International Energy Agency, IEA, 2019. The Future of Rail. Opportunities for energy and the environment. https://www.iea. org/reports/the-future-of-rail

12. Leunig T., 2011, Cart or Horse: Transport and Economic Growth. Discussion Paper No. 2011-04, OECD/ITF 2011.

13. Massel A., 2006, 25 lat kolei dużych prędkości we Francji, Technika Transportu Szynowego nr 10.

14. United Nations, UN, 1987. Report of the World Commission on Environment and Development, "Our Common Future", Oslo. 